\title{
Effects of Peers and Family Members on Smoking Habits in Adolescents: A Meta-Analysis
}

\author{
Florida Betty Apriliyani'), Agus Kristiyanto'), Bhisma Murti') \\ 1)Masters Program in Public Health, Universitas Sebelas Maret \\ ${ }^{2}$ Study Program in Sports Education and Health Sciences, Universitas Sebelas Maret
}

\section{ABSTRACT}

Background: Nowadays, smoking is one of the biggest public health problems worldwide. It is a major cause of disease and mortality that can be prevented early. One out of 10 deaths worldwide is caused by tobacco use. 40 million people died each year due to tobacco. Adolescents start smoking in response to social effects, imitating the behavior of friends, family members, and others they admire. This metaanalysis study aimed to analyze the effect of peers and family members who smoked on smoking habits in adolescents.

Subjects and Method: Meta-analysis was conducted by searching for articles from databases such as PubMed, SpringerLink, Elsevier, Science Direct, and Google Scholar. The keywords were "peers" OR "parenting style" OR "family influence" AND "smoking" AND "behavior" AND "adolescents" AND "cross-sectional". The inclusion criteria were full-text articles with a cross-sectional design, English and Indonesian languages, students aged 14-24 years as the study subjects. The final results of the study were presented using the adjusted odds ratio (aOR). The articles were analyzed using Revman 5.3 software.

Results: 17 articles were analyzed. The results showed that peers and family members increased smoking habits in adolescents; the result was statistically significant with peers $(\mathrm{aOR}=2.77 ; 95 \% \mathrm{CI}=1.67$ to $4.60 ; \mathrm{p}<0.001$; $\left.\mathrm{I}^{2}=96 \%\right)$ and family members $(\mathrm{aOR}=1.69 ; 95 \%$ $\mathrm{CI}=1.35$ to $\left.2.13 ; \mathrm{p}<0.001 ; \mathrm{I}^{2}=65 \%\right)$.

Conclusion: Peers and family members affects smoking habits in adolescents. It is statistically significant.

Keywords: Peers, family members, smoking habits, adolescents, cross-sectional

\section{Correspondence:}

Florida Betty Apriliyani. Masters Program in Public Health, Universitas Sebelas Maret, Jl. Ir. Sutami 36A, Surakarta 57126, Central Java. Email: ridhaflorida@gmail.com. Mobile: 081329329417.

\section{Cite this as:}

Apriliyani FB, Kristiyanto A, Murti B (2020). Effects of Peers and Family Members on Smoking Habits in Adolescents: A Meta-Analysis. J Health Promote Behav. 05(04): 248-263. https://doi.org/10.26911/thejhpb.2020.05.04.03.

(c) (i) (2) Journal of Health Promotion and Behavioris licensed under a Creative Commons c)

\section{BACKGROUND}

Nowadays, smoking is one of the biggest public health problems worldwide. It is a major cause of disease and mortality that can be prevented early (Ball et al., 2018).

The World Health Organization (WHO) stated that more than 4 million deaths occurred in a year due to tobacco. It increased to 10 million deaths per year by 2020. In American States, 440,000 people died each year due to diseases caused by smoking. In addition, 5.6 million people lost potential lives, 82 billion people lost productivity, and 75 billion people were in direct medical costs (Reda et al, 2019).

In general, smoking occurs during adolescence which results in smoking behavior in adult life (Moor et al., 2015). Smoking behavior is an activity of burning cigarettes or tobacco, inhaling the smoke, exhaling it, and repeating it until the cigarette runs out (Riadinata, 2018). 
Apriliyani et al./ Effects of Peers and Family Members on Smoking Habits in Adolescents

According to the ecological systems theory, an understanding of individual behavior must consider the environmental system where the individual is embedded as each system includes roles, norms, and rules that affect one another, thus building adolescents development. Smoking in adolescents is strongly associated with psychosocial factors in the family, school, and peer groups. Peer networks play an important role in smoking behavior in adolescents (Simetin et al., 2011).

Currently, there are around 1.2 billion smokers worldwide, which is close to $20 \%$ of the world's population in 2014 (World Cancer Report-WHO, 2014). The results of a study by the WHO Report On The Global Tobacco Epidemic 2011 found that smoking habits did not only occur in developed countries, but also in developing countries in the African continent and the Asian region (WHO, 2015).

1.2 billion smokers were currently found in several regions: Asia Pacific by $56 \%$, Europe by $24 \%$, USA by $11 \%$, and Africa and the Middle East by 9\%. 10\% or 121 million of these smokers came from 10 countries in the Southeast Asia, thus making this region had the largest number of smokers in the Asia Pacific. It contributed $20 \%$ of the causes of global tobacco deaths (SEATCA, 2014). Among the 1 billion smokers worldwide, 50\% were young people consumed 6 trillion cigarettes per year. In 2020, 7 out of 10 smoking deaths would occur in LMICs (low- and middle-income countries). If current trends continue, tobacco would kill more than 8 million people worldwide each year by 2030 (Aryal, 2014). Based on these data, the authors were interested in investigating the effects of peers and family members on smoking habits in adolescents.

\section{SUBJECTS AND METHOD}

\section{Study Design}

This study was a systematic review and a meta-analysis. This study used secondary data from previous study results. The articles were obtained from several databases including PubMed, SpringerLink, Elsevier, Science Direct, and Google Scholar. The keywords were "peers" OR "parenting style" OR "family influence" AND "smoking" AND "behavior" AND "adolescents" AND "crosssectional".

\section{Inclusion Criteria}

The inclusion criteria were full-text articles with a cross-sectional study design and using English and Indonesian languages. The study subjects were students aged 1424 years. The final results of the study were presented using the adjusted odds ratio (aOR).

\section{Exclusion Criteria}

The exclusion criteria were non-full-text articles, non-English articles, and published before 2000.

\section{Operational Definition of Variables}

The article search was carried out by considering the eligibility criteria defined using the PICO model. The population of this study was adolescents. The intervention was peers and family members who smoked. The comparison was peers and family members who did not smoke. The outcomes were smoking habits.

Peers were people with a level of age and maturity that was about more or less the same, namely at the age of 12 and 13 years.

Family was one of the first environments for a child or adolescent to get more knowledge before leaving the family circle. Family members consisted of father, mother, brother, and sister.

\section{Data Analysis}

The data were processed using the Review Manager (RevMan 5.3). This study used a random-effect model. 
Apriliyani et al./ Effects of Peers and Family Members on Smoking Habits in Adolescents

\section{RESULTS}

The process of searching for articles through databases with journals is in Figure
1. The articles were obtained from 4 continents: Asia, Europe, America, and Africa.

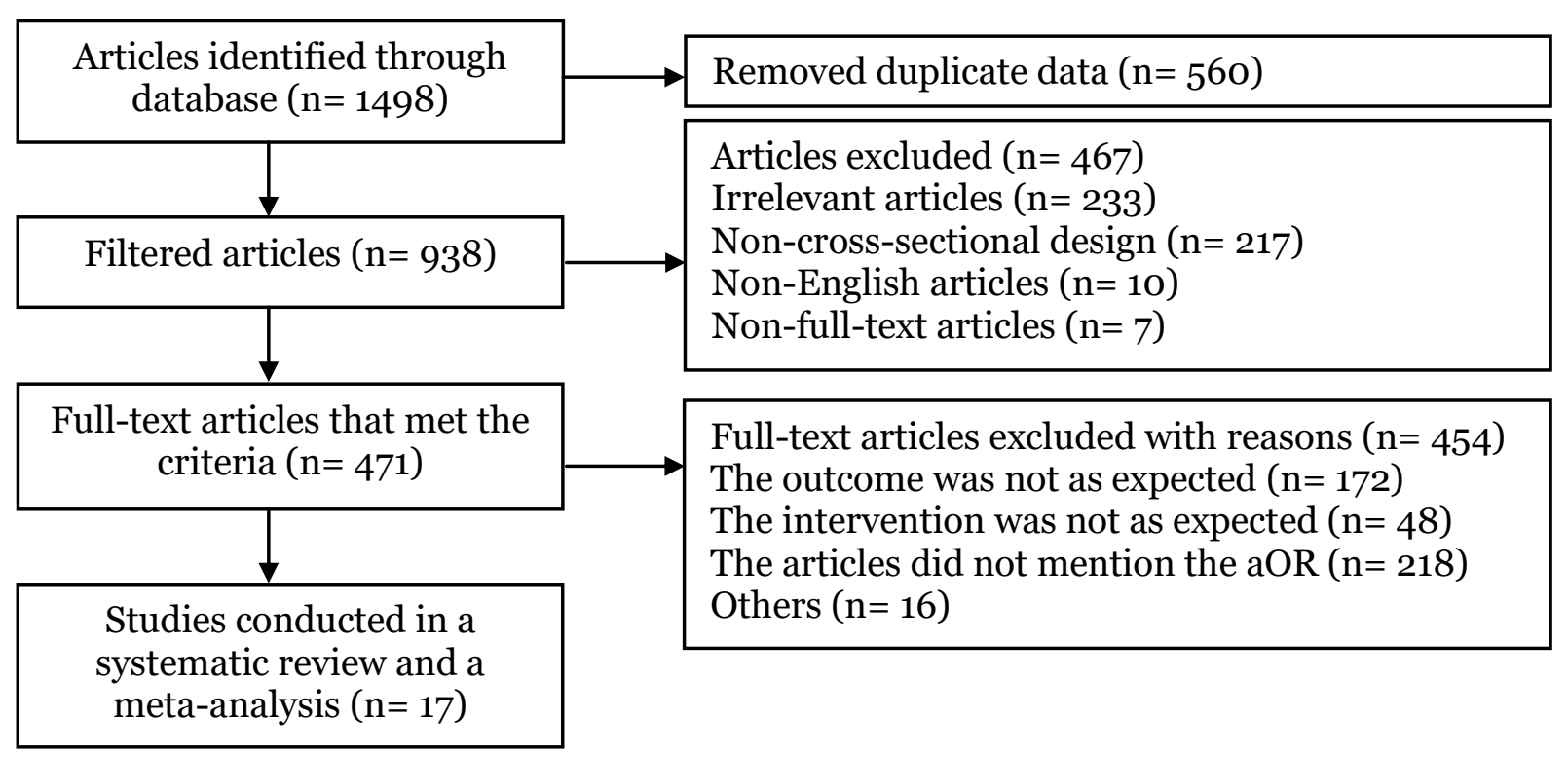

Figure 1. PRISMA flow diagram 
1. The effects of peers on smoking habits in adolescents

a. Summary Source

Table 1. The description of the primary study included in the meta-analysis

\begin{tabular}{|c|c|c|c|c|c|c|}
\hline $\begin{array}{c}\text { Author } \\
\text { (year) }\end{array}$ & Title & Country & $\begin{array}{c}\text { Study } \\
\text { design }\end{array}$ & $\begin{array}{l}\text { Population and } \\
\text { Sample }\end{array}$ & $\begin{array}{l}\text { Intervention (I) and } \\
\text { Comparison (C) }\end{array}$ & Outcome \\
\hline $\begin{array}{l}\text { Aryal et al. } \\
(2014)\end{array}$ & $\begin{array}{l}\text { Correlates of smoking susceptibility } \\
\text { among adolescents in a peri-urban area of } \\
\text { Nepal: A population-based-cross-sectional } \\
\text { study in the Jhaukel-Duwakot health } \\
\text { demographic surveillance site }\end{array}$ & Nepal & $\begin{array}{l}\text { Cross- } \\
\text { sectional }\end{array}$ & $\begin{array}{l}352 \text { male and female } \\
\text { respondents aged 14- } \\
16 \text { years }(n=500)\end{array}$ & $\begin{array}{l}\text { I: Peers who smoked } \\
\text { C: Peers who did not } \\
\text { smoke }\end{array}$ & $\begin{array}{l}\text { Peers affected } \\
\text { smoking habits (it } \\
\text { increased } 2.45 \text { times } \\
\text { the susceptibility to } \\
\text { smoke) }\end{array}$ \\
\hline $\begin{array}{l}\text { Backhouse et } \\
\text { al. (2017) }\end{array}$ & $\begin{array}{l}\text { Link between perceived smoking beha- } \\
\text { viour at school and student smoking } \\
\text { status: A large survey among Italian } \\
\text { adolescents }\end{array}$ & Italy & $\begin{array}{l}\text { Cross- } \\
\text { sectional }\end{array}$ & $\begin{array}{l}1.889 \text { students aged } \\
14-19 \text { years }(44 \% \\
\text { males and } 56 \% \\
\text { females }) \\
(n=1,889)\end{array}$ & $\begin{array}{l}\text { I: Peers who smoked } \\
\text { C: Peers who did not } \\
\text { smoke }\end{array}$ & $\begin{array}{l}\text { Peers increased the } \\
\text { susceptibility to } \\
\text { smoke in adolescents }\end{array}$ \\
\hline $\begin{array}{l}\text { Gaffar et al. } \\
\text { (2013) }\end{array}$ & $\begin{array}{l}\text { Sociodemographic factors associated with } \\
\text { tobacco smoking among intermediate ad } \\
\text { secondary school students in Jazan } \\
\text { Region of Saudi Arabia }\end{array}$ & $\begin{array}{l}\text { Saudi } \\
\text { Arabia }\end{array}$ & $\begin{array}{l}\text { Cross- } \\
\text { sectional }\end{array}$ & $\begin{array}{l}3.923 \text { males and } \\
\text { females aged } 15^{-19} \\
\text { years } \\
(n=4.100)\end{array}$ & $\begin{array}{l}\text { I: Peers who smoked } \\
\text { C: Peers who did not } \\
\text { smoke }\end{array}$ & $\begin{array}{l}\text { Peers increased the } \\
\text { prevalence of } \\
\text { smoking habits } \\
\text { (males; } 19.1 \% \text { and } \\
\text { female } 4.7 \% \text { ) }\end{array}$ \\
\hline $\begin{array}{l}\text { Hock et al. } \\
(2014)\end{array}$ & $\begin{array}{l}\text { Prevalence and factors associated with } \\
\text { smoking intentions among non-smoking } \\
\text { and smoking adolescents in Kota Tinggi, } \\
\text { Johor, Malaysia }\end{array}$ & Malaysia & $\begin{array}{l}\text { Cross- } \\
\text { sectional }\end{array}$ & $\begin{array}{l}2.300 \text { high school } \\
\text { students aged 13-16 } \\
\text { years }\end{array}$ & $\begin{array}{l}\text { I: Best friends or peers } \\
\text { who smoked } \\
\text { C: Best friends or peers } \\
\text { who did not smoke }\end{array}$ & $\begin{array}{l}\text { Best friends or peers } \\
\text { who smoked affected } \\
\text { smoking habits }\end{array}$ \\
\hline $\begin{array}{l}\text { Huang et al. } \\
\text { (2012) }\end{array}$ & $\begin{array}{l}\text { Analysis of influential factors associated } \\
\text { with the smoking behavior of Aboriginal } \\
\text { school children in remote Taiwanese } \\
\text { mountainous areas }\end{array}$ & Taiwan & $\begin{array}{l}\text { Cross- } \\
\text { sectional }\end{array}$ & $\begin{array}{l}630 \text { males and } 609 \\
\text { females of high } \\
\text { school students aged } \\
\pm 14 \text { years }(n=1,239)\end{array}$ & $\begin{array}{l}\text { I: Peers or best friends } \\
\text { who smoked } \\
\text { C: Peers or best friends } \\
\text { who did not smoke }\end{array}$ & $\begin{array}{l}\text { Peers/best friends } \\
\text { are a greater } \\
\text { predictor of smoking } \\
\text { habits in adolescents }\end{array}$ \\
\hline $\begin{array}{l}\text { Leatherdale et } \\
\text { al. (2010) }\end{array}$ & $\begin{array}{l}\text { The influence of friends, family, and older } \\
\text { peers on smoking among elementary } \\
\text { school students: Low risk students in } \\
\text { high-risk schools }\end{array}$ & Canada & $\begin{array}{l}\text { Cross- } \\
\text { sectional }\end{array}$ & $\begin{array}{l}4.286 \text { students in the } \\
6 \text { th and } 7 \text { th grade of } \\
57 \text { primary schools } \\
\text { aged } \pm 12 \text { years }\end{array}$ & $\begin{array}{l}\text { I: Peers who smoked } \\
\text { C: Peers who did not } \\
\text { smoke }\end{array}$ & $\begin{array}{l}\text { Peers who smoked } \\
\text { significantly } \\
\text { increased smoking } \\
\text { habits in adolescents }\end{array}$ \\
\hline $\begin{array}{l}\text { Lim et al. } \\
(2020)\end{array}$ & $\begin{array}{l}\text { Smoking among school-going adolescents } \\
\text { in selected secondary school in Peninsular } \\
\text { Malaysia-Finding from the Malaysian } \\
\text { adolescents health risk behaviour }\end{array}$ & Malaysia & $\begin{array}{l}\text { Cross- } \\
\text { sectional }\end{array}$ & $\begin{array}{l}2.991 \text { high school } \\
\text { students aged 16-17 } \\
\text { years }\end{array}$ & $\begin{array}{l}\text { I: Peers who smoked } \\
\text { C: Peers who did not } \\
\text { smoke }\end{array}$ & $\begin{array}{l}\text { Peers increased } \\
\text { smoking habits in } \\
\text { adolescents. The } \\
\text { prevalence of }\end{array}$ \\
\hline
\end{tabular}




\begin{tabular}{|c|c|c|c|c|c|c|}
\hline $\begin{array}{l}\text { Moor et al. } \\
(2015)\end{array}$ & $\begin{array}{l}\text { (MyaHRB) Study } \\
\text { Socioeconomic inequalities in adolescents } \\
\text { smoking across } 35 \text { countries: A multilevel } \\
\text { analysis of the role of family, school, and } \\
\text { peers }\end{array}$ & Europe & $\begin{array}{l}\text { Cross- } \\
\text { sectional }\end{array}$ & $\begin{array}{l}52.907 \text { students aged } \\
15 \text { years from } 35 \\
\text { countries in Europe } \\
\text { dan South America }\end{array}$ & $\begin{array}{l}\text { I: Peers who smoked } \\
\text { C: Peers who did not } \\
\text { smoke }\end{array}$ & $\begin{array}{l}\text { smoking was } 14.6 \% \\
\text { Peers increased } \\
\text { smoking habits by } \\
100 \% \text { in males and } \\
81 \% \text { in females }\end{array}$ \\
\hline $\begin{array}{l}\text { Purnaningrum } \\
\text { et al. (2017) }\end{array}$ & $\begin{array}{l}\text { Association between cigarete advertise- } \\
\text { ment, peer group, parental education, } \\
\text { family income, and pocket money with } \\
\text { smoking behavior among adolescents in } \\
\text { Karanganyar District, Central Java }\end{array}$ & Indonesia & $\begin{array}{l}\text { Cross- } \\
\text { sectional }\end{array}$ & $\begin{array}{l}100 \text { adolescents aged } \\
14-24 \text { years }\end{array}$ & $\begin{array}{l}\text { I: Peer group who smoked } \\
\text { C: Peer group who did not } \\
\text { smoke }\end{array}$ & $\begin{array}{l}\text { Peers group with } \\
\text { high smoking habits } \\
\text { would increase } \\
\text { smoking habits } \\
\text { among adolescents }\end{array}$ \\
\hline $\begin{array}{l}\text { Reda et al. } \\
(2012)\end{array}$ & $\begin{array}{l}\text { Determinants of Cigarette Smoking } \\
\text { Among School Adolescents in Eastern } \\
\text { Ethiopia: A Cross- Sectional Study }\end{array}$ & Ethiopia & $\begin{array}{l}\text { Cross- } \\
\text { sectional }\end{array}$ & $\begin{array}{l}1.721 \text { school-age } \\
\text { children aged } 13-19 \\
\text { years } \\
(n=1,890)\end{array}$ & $\begin{array}{l}\text { I: Peers who smoked } \\
\text { C: Peers who did not } \\
\text { smoke }\end{array}$ & $\begin{array}{l}\text { Peers who smoked } \\
\text { were important } \\
\text { determinants of } \\
\text { smoking behavior } \\
\text { and habits in adoles- } \\
\text { cents (32.4\%), the } \\
\text { prevalence was } 11.8 \% \\
\text { in males and } 1.1 \% \text { in } \\
\text { females. }\end{array}$ \\
\hline $\begin{array}{l}\text { Simetin et al } \\
(2010)\end{array}$ & $\begin{array}{l}\text { Inequalities in Croatian pupils' unhealthy } \\
\text { behaviours and health outcomes: Role of } \\
\text { school, peers, and family affluence }\end{array}$ & Europe & $\begin{array}{l}\text { Cross- } \\
\text { sectional }\end{array}$ & $\begin{array}{l}1.166 \text { children aged } \\
11 \text { years and } 1,630 \\
\text { children aged } 15 \\
\text { years }\end{array}$ & $\begin{array}{l}\text { I: Peers who smoked } \\
\text { C: Peers who did not } \\
\text { smoke }\end{array}$ & $\begin{array}{l}41,0 \% \text { of peers who } \\
\text { smoked affected } \\
\text { smoking habits in } \\
\text { adolescents }\end{array}$ \\
\hline $\begin{array}{l}\text { Skullberg et al } \\
\text { (2019) }\end{array}$ & $\begin{array}{l}\text { Smoking adolescents males at Pulau Weh, } \\
\text { Indonesia }\end{array}$ & Indonesia & $\begin{array}{l}\text { Cross- } \\
\text { sectional }\end{array}$ & $\begin{array}{l}291 \text { male students } \\
\text { aged } 13-15 \text { years }\end{array}$ & $\begin{array}{l}\text { I: Peers who smoked } \\
\text { C: Peers who did not } \\
\text { smoke }\end{array}$ & $\begin{array}{l}40 \% \text { of peers who } \\
\text { smoked affected } \\
\text { smoking habits in } \\
\text { adolescents }\end{array}$ \\
\hline
\end{tabular}


Apriliyani et al./ Effects of Peers and Family Members on Smoking Habits in Adolescents

\section{b. Forest Plot}

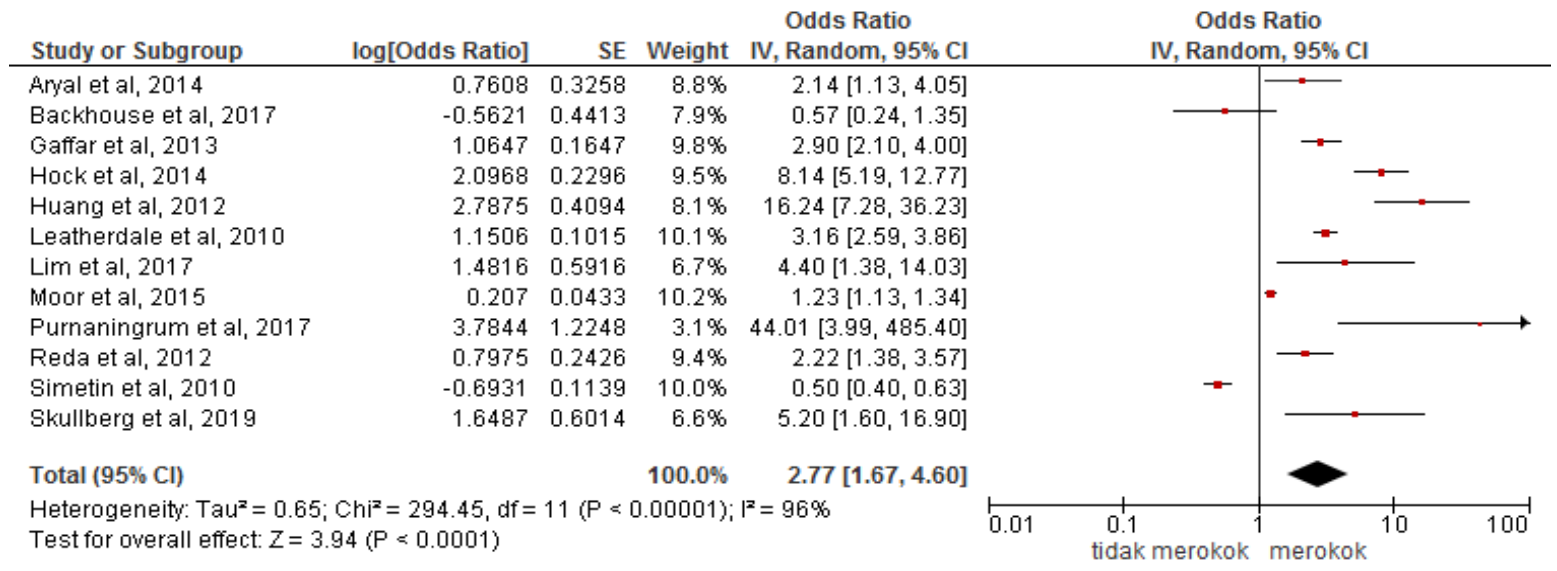

\section{Figure 3. The forest plot of the effects of peers on smoking habits in adolescents}

The interpretation of the results from the meta-analysis process can be seen through a forest plot. Figure 3 shows that peers who smoked 2.77 times significantly increased smoking habits in adolescents $(\mathrm{aOR}=2.77 ; 95 \% \mathrm{CI}=1.67$ to $4.60 ; \mathrm{p}<0.001$; $\left.\mathrm{I}^{2}=96 \%\right)$. Therefore, the distribution of data was heterogeneous (random-effect model).

\section{c. Funnel Plot}

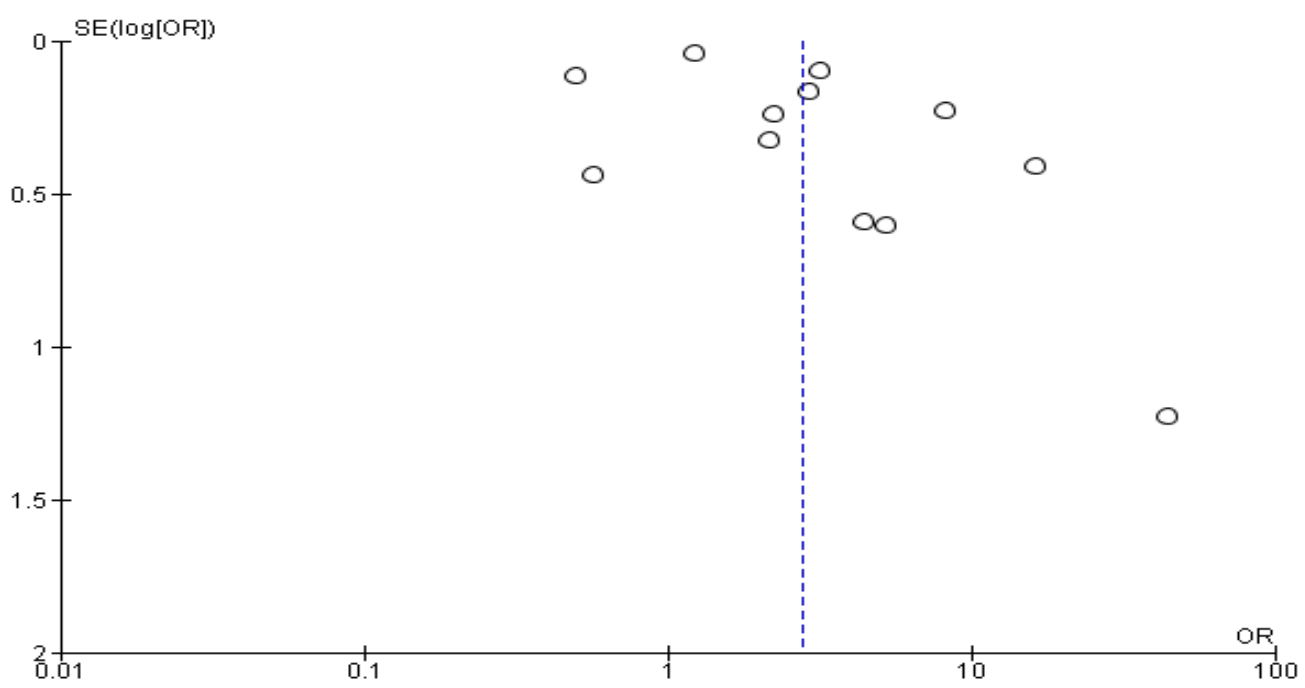

\section{Gambar 4. The funnel plot of the effects of peers on smoking habits in adolescents}

Based on figure 4, there was no publication bias indicated by the symmetrical plots on the right and left, where 7 plots were on the right and 5 plots were on the left. The plot on the left of the graph had a standard error between 0 and 0.5 . Besides, the plot on the right had a standard error between 0 and 0.5 . 


\section{The effects of family members on smoking habits in adolescents}

\section{a. Summary Source}

Table 2. The description of the primary study included in the meta-analysis

\begin{tabular}{|c|c|c|c|c|c|c|}
\hline $\begin{array}{c}\text { Author } \\
\text { (year) }\end{array}$ & Title & Country & $\begin{array}{c}\text { Study } \\
\text { design }\end{array}$ & $\begin{array}{c}\text { Population and } \\
\text { sample }\end{array}$ & $\begin{array}{c}\text { Intervention (I) and } \\
\text { Comparison (C) }\end{array}$ & Outcome \\
\hline $\begin{array}{l}\text { Alves et al. } \\
(2016)\end{array}$ & $\begin{array}{l}\text { The role of parental smoking on } \\
\text { adolescentsmoking and its social } \\
\text { patterning: A cross-sectional } \\
\text { survey in six Euoropean cities }\end{array}$ & Europe & $\begin{array}{l}\text { Cross- } \\
\text { sectional }\end{array}$ & $\begin{array}{l}11,015 \text { male and } \\
\text { female students as } \\
\text { the respondents } \\
\text { aged } 14-16 \text { years }\end{array}$ & $\begin{array}{l}\text { I: Family members (parents) } \\
\text { who smoked } \\
\text { C: Family members (parents) } \\
\text { who did not smoke }\end{array}$ & $\begin{array}{l}\text { The prevalence of parents } \\
\text { who smoked was higher } \\
\text { occurred in adolescents } \\
\text { with low socioeconomic } \\
\text { status }\end{array}$ \\
\hline $\begin{array}{l}\text { Bakhruji et } \\
\text { al. (2017) }\end{array}$ & $\begin{array}{l}\text { Carious lesions of permanent } \\
\text { molars and oral health practices } \\
\text { of parents and peers in Saudi } \\
\text { male adolescents }\end{array}$ & $\begin{array}{l}\text { Saudi } \\
\text { Arabia }\end{array}$ & $\begin{array}{l}\text { Cross- } \\
\text { sectional }\end{array}$ & $\begin{array}{l}294 \text { students aged } \\
12-15 \text { years }\end{array}$ & $\begin{array}{l}\text { I: Family members who } \\
\text { smoked } \\
\text { C: Family members who did } \\
\text { not smoke }\end{array}$ & $\begin{array}{l}\text { Family members increased } \\
\text { the susceptibility to smoke } \\
\text { in adolescents }\end{array}$ \\
\hline $\begin{array}{l}\text { Hashmi et al. } \\
(2014)\end{array}$ & $\begin{array}{l}\text { Family and peer effect on young } \\
\text { and adolescent smoking in } \\
\text { Bangladesh }\end{array}$ & Bangladesh & $\begin{array}{l}\text { Cross- } \\
\text { sectional }\end{array}$ & $\begin{array}{l}995 \text { male students } \\
\text { aged 10-24 years }\end{array}$ & $\begin{array}{l}\text { I: Family members who } \\
\text { smoked } \\
\text { C: Family members who did } \\
\text { not smoke }\end{array}$ & $\begin{array}{l}45 \% \text { of adolescents were } \\
\text { more susceptible to smoke } \\
\text { if there were family } \\
\text { members who smoked }\end{array}$ \\
\hline $\begin{array}{l}\text { Hock et al. } \\
(2014)\end{array}$ & $\begin{array}{l}\text { Prevalence and factors associated } \\
\text { with smoking intentions among } \\
\text { non-smoking and smoking } \\
\text { adolescents in Kota Tinggi, Johor, } \\
\text { Malaysia }\end{array}$ & Malaysia & $\begin{array}{l}\text { Cross- } \\
\text { sectional }\end{array}$ & $\begin{array}{l}2.300 \text { high school } \\
\text { students aged 13-16 } \\
\text { years }\end{array}$ & $\begin{array}{l}\text { I: Family members who } \\
\text { smoked } \\
\text { C: Family members who did } \\
\text { not smoke }\end{array}$ & $\begin{array}{l}\text { Family members who } \\
\text { smoked affected smoking } \\
\text { habits }\end{array}$ \\
\hline $\begin{array}{l}\text { Huang et al. } \\
(2012)\end{array}$ & $\begin{array}{l}\text { Analysis of influential factors } \\
\text { associated with the smoking } \\
\text { behavior of Aboriginal school } \\
\text { children in remote Taiwanese } \\
\text { mountainous areas }\end{array}$ & Taiwan & $\begin{array}{l}\text { Cross- } \\
\text { sectional }\end{array}$ & $\begin{array}{l}630 \text { males and } 609 \\
\text { females of school- } \\
\text { age children aged } \\
\pm 14 \text { years }(\mathrm{n}= \\
1.239)\end{array}$ & $\begin{array}{l}\text { I: Family members who } \\
\text { smoked } \\
\text { C: Family members who did } \\
\text { not smoke }\end{array}$ & $\begin{array}{l}\text { Family who smoked was a } \\
\text { stronger predictor of } \\
\text { smoking habits in } \\
\text { adolescents }\end{array}$ \\
\hline $\begin{array}{l}\text { Lehtren et al. } \\
(2020)\end{array}$ & $\begin{array}{l}\text { School achievement and oral } \\
\text { health behaviour among adoles- } \\
\text { cents in Finland: A national } \\
\text { survey }\end{array}$ & Finland & $\begin{array}{l}\text { Cross- } \\
\text { sectional }\end{array}$ & $\begin{array}{l}45.877 \text { students } \\
\text { aged } 14-20 \text { years }\end{array}$ & $\begin{array}{l}\text { I: Family members (parents) } \\
\text { who smoked } \\
\text { C: Family members (parents) } \\
\text { who did not smoke }\end{array}$ & $\begin{array}{l}\text { Family members (parents) } \\
\text { affected smoking habits in } \\
\text { adolescents }\end{array}$ \\
\hline $\begin{array}{l}\text { Li et al. } \\
(2020)\end{array}$ & $\begin{array}{l}\text { Prevalence of Smoking and Its } \\
\text { Associated Risk Factors Among } \\
\text { Secondary School Students in } \\
\text { Kelantan, Malaysia }\end{array}$ & Malaysia & $\begin{array}{l}\text { Cross } \\
\text { sectional }\end{array}$ & $\begin{array}{l}1.500 \text { male and } \\
\text { females students } \\
\text { aged } 13-17 \text { years }\end{array}$ & $\begin{array}{l}\text { I: Family members who } \\
\text { smoked } \\
\text { C: Family members who did } \\
\text { not smoke }\end{array}$ & $\begin{array}{l}\text { Family members who } \\
\text { smoked affected smoking } \\
\text { habits in adolescents }\end{array}$ \\
\hline
\end{tabular}


Apriliyani et al./ Effects of Peers and Family Members on Smoking Habits in Adolescents

\begin{tabular}{|c|c|c|c|c|c|c|}
\hline $\begin{array}{l}\text { Lim et al. } \\
(2020)\end{array}$ & $\begin{array}{l}\text { Smoking among school-going } \\
\text { adolescents in selected secondary } \\
\text { school in Peninsular Malaysia- } \\
\text { Finding From the Malaysian } \\
\text { adolescents health risk behaviour } \\
\text { (MyaHRB) Study }\end{array}$ & Malaysia & $\begin{array}{l}\text { Cross- } \\
\text { sectional }\end{array}$ & $\begin{array}{l}2.991 \text { high school } \\
\text { students aged 16-17 } \\
\text { years }\end{array}$ & $\begin{array}{l}\text { I: Family members who } \\
\text { smoked (parents who } \\
\text { smoked and or a parent who } \\
\text { smoked) } \\
\text { C: Family members who did } \\
\text { not smoke }\end{array}$ & $\begin{array}{l}\text { Family members who } \\
\text { smoked (parents who } \\
\text { smoked and/or parents } \\
\text { who smoked) increased } \\
\text { smoking habits in } \\
\text { adolescents. The prevalence } \\
\text { of smoking was } 14.6 \%\end{array}$ \\
\hline $\begin{array}{l}\text { Reda et al. } \\
\text { (2012) }\end{array}$ & $\begin{array}{l}\text { Determinants of cigarette } \\
\text { smoking among school } \\
\text { adolescents in Eastern Ethiopia: A } \\
\text { Cross-Sectional Study }\end{array}$ & Ethiopia & $\begin{array}{l}\text { Cross- } \\
\text { sectional }\end{array}$ & $\begin{array}{l}1.721 \text { adolescents } \\
\text { aged } 13-19 \text { years } \\
(n=1,890)\end{array}$ & $\begin{array}{l}\text { I: Family members who } \\
\text { smoked } \\
\text { C: Family members who did } \\
\text { not smoke }\end{array}$ & $\begin{array}{l}\text { Family members who } \\
\text { smoked were important } \\
\text { determinants of smoking } \\
\text { behavior and habits in } \\
\text { adolescents with a } \\
\text { prevalence of } 11.8 \% \text { in } \\
\text { males and } 1.1 \% \text { in females }\end{array}$ \\
\hline
\end{tabular}


Apriliyani et al./ Effects of Peers and Family Members on Smoking Habits in Adolescents

\section{b. Forest Plot}

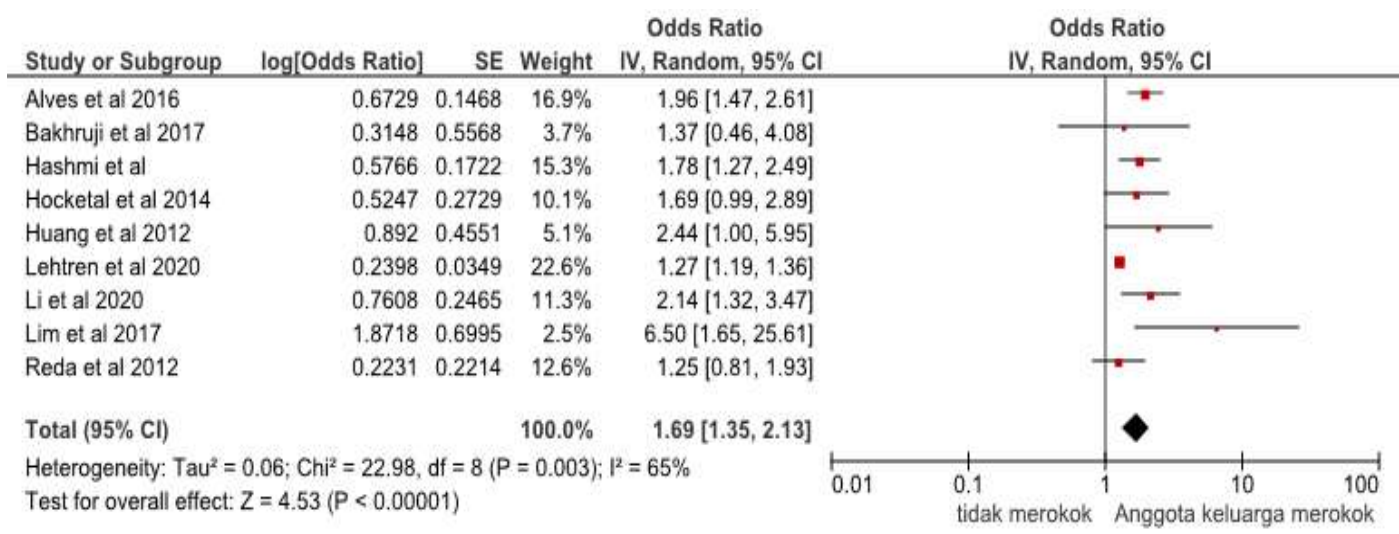

\section{Figure 5. The effects of family members on smoking habits in adolescents}

The interpretation of the results from the meta-analysis process can be seen through a forest plot. Figure 5 shows that family members who smoked 1.69 times significantly increased smoking habits in adolescents $(\mathrm{aOR}=1.69 ; 95 \% \mathrm{CI}=1.35$ to 2.13; $\left.\mathrm{p}<0.001 ; \mathrm{I}^{2}=65 \%\right)$. Therefore, the distribution of data was heterogeneous (random-effect model).

\section{c. Funnel Plot}

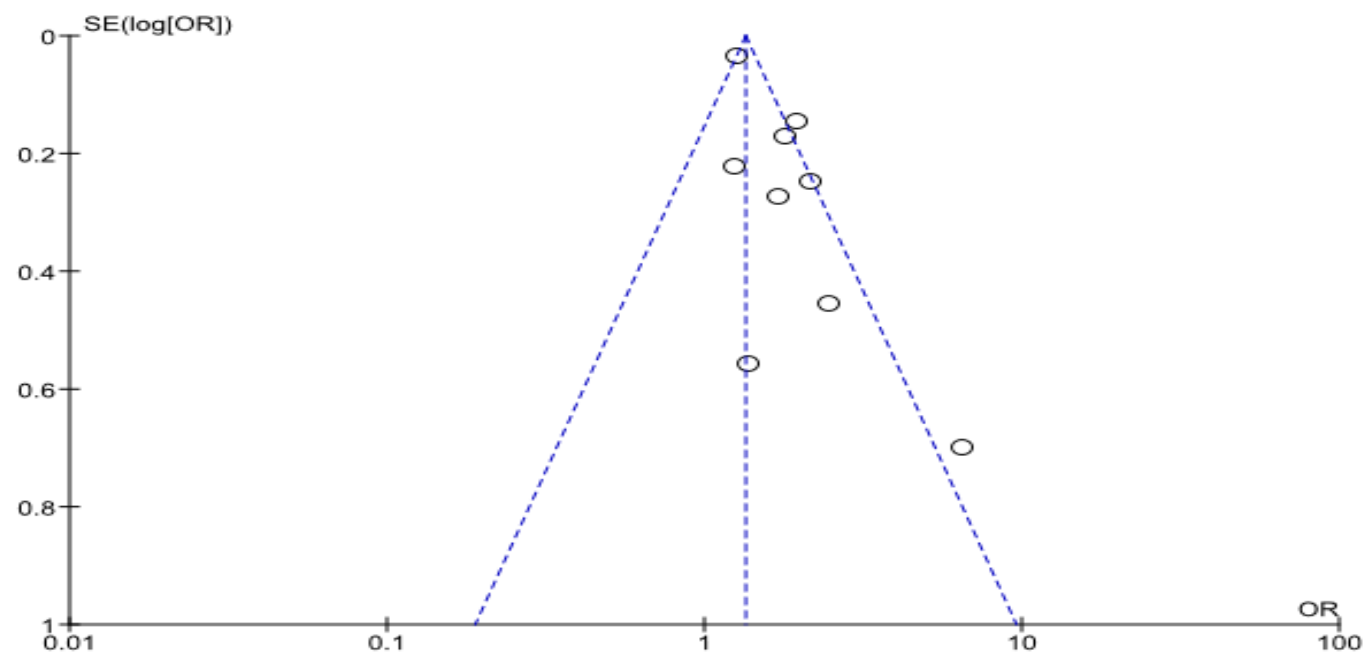

Figure 6. The funnel plot of the effects of family members on smoking habits in adolescents

Based on figure 4, there was no publication bias indicated by the symmetrical plots on the right and left, where 6 plots were on the right and 3 plots were on the left. The plot on the left of the graph had a standard error between 0 and o.1. Besides, the plot on the right had a standard error between o and o.8. 
Apriliyani et al./ Effects of Peers and Family Members on Smoking Habits in Adolescents

Table 3. The assessment of Study Quality of Peers and family members on smoking habits in adolescents

\begin{tabular}{lccccccccccccc}
\hline \multicolumn{1}{c}{ Primary Study } & \multicolumn{1}{c}{ Criteria } \\
\cline { 2 - 12 } & $\mathbf{1}$ & $\mathbf{2}$ & $\mathbf{3}$ & $\mathbf{4}$ & $\mathbf{5}$ & $\mathbf{6}$ & $\mathbf{7}$ & $\mathbf{8}$ & $\mathbf{9}$ & $\mathbf{1 0}$ & $\mathbf{1 1}$ & $\mathbf{1 2}$ & Total \\
\hline Aryal et al. (2014) & 1 & 1 & 1 & 1 & 1 & 0 & 1 & 1 & 1 & 1 & 0 & 1 & 10 \\
Backhouse et al. (2017) & 1 & 1 & 1 & 1 & 1 & 1 & 1 & 1 & 1 & 0 & 1 & 1 & 11 \\
Gaffar et al.(2013) & 1 & 1 & 1 & 1 & 1 & 0 & 0 & 1 & 1 & 1 & 1 & 1 & 10 \\
Hock et al. (2014) & 1 & 1 & 1 & 1 & 1 & 0 & 1 & 1 & 0 & 1 & 1 & 1 & 10 \\
Huang et al. (2012) & 1 & 1 & 1 & 1 & 1 & 1 & 1 & 1 & 1 & 1 & 1 & 1 & 12 \\
Leatherdale et al. (2010) & 1 & 1 & 1 & 1 & 1 & 1 & 1 & 1 & 0 & 1 & 0 & 1 & 10 \\
Lim et al. (2017) & 1 & 1 & 1 & 1 & 1 & 0 & 1 & 1 & 0 & 1 & 0 & 1 & 9 \\
Moor et al. (2015) & 1 & 1 & 0 & 1 & 1 & 1 & 1 & 1 & 1 & 1 & 0 & 1 & 10 \\
Purnaningrum et al. (2017) & 1 & 1 & 1 & 1 & 1 & 0 & 1 & 1 & 0 & 0 & 1 & 1 & 9 \\
Reda et al. (2012) & 1 & 1 & 1 & 1 & 1 & 0 & 0 & 1 & 1 & 1 & 1 & 1 & 10 \\
Simetin et al (2010) & 1 & 1 & 0 & 1 & 1 & 1 & 1 & 1 & 1 & 1 & 0 & 1 & 10 \\
Skulberg et al (2019) & 1 & 1 & 1 & 1 & 1 & 1 & 1 & 1 & 1 & 1 & 1 & 1 & 12 \\
Alvest et al. (2016) & 1 & 1 & 1 & 1 & 1 & 0 & 1 & 1 & 0 & 0 & 1 & 1 & 9 \\
Bakhruji et al. (2017) & 1 & 1 & 1 & 1 & 1 & 0 & 0 & 1 & 1 & 1 & 1 & 1 & 10 \\
Hashmi et al. (2014) & 1 & 1 & 1 & 1 & 1 & 1 & 1 & 1 & 0 & 1 & 0 & 1 & 10 \\
Lehtren et al. (2020) & 1 & 1 & 1 & 1 & 1 & 1 & 1 & 1 & 1 & 1 & 1 & 1 & 12 \\
Li et al. (2020) & 1 & 1 & 0 & 1 & 1 & 1 & 1 & 1 & 1 & 1 & 0 & 1 & 10 \\
\hline
\end{tabular}

Note in Table 3:

1. Were the objectives clearly discussed the focus/study problem?

2. Was the study method (study design) suitable for answering study questions?

3. Was the method of selecting study subjects clearly written?

4. Did the sampling method create bias (selection)?

5 . Did the sample taken represent the designated population?

6. Was the sample size based on pre-study considerations?

7. Was a satisfactory response achieved?

8. Was the study instrument valid and reliable?

9. Was statistical significance assessed?

10. Were confidence intervals given for the main outcome?

11. Were there any counfounding factors that have not been considered?

12. Were the results applicable to your study?

\section{DISCUSSION}

This systematic study and meta-analysis study proposed the theme of the effects of peers and family members on smoking habits in adolescents. The independent variable was smoking. A study that discussed data on smoking habits in adolescents was important because there were only several relevant studies published and accessible and it had data access problems (data duplication) (Murti, 2018). Most of the statistical results reported were in the form of a percentage or a crude odd ratio (cOR), where the study did not control for confounding factors.

Confounding factors that affected the relationship or effect of exposure to the occurrence of disease estimated by the study was not the same as the relationship or effect that occurred in the target population, which means that the study result was invalid (incorrect) (Murti, 2018). This systematic and meta-analysis study used a study that controlled for confounding factors. It was shown from the inclusion criteria, namely multivariate analysis. The 
statistical result was in the form of the adjusted odd ratio (aOR).

Estimates of the combined effect of peers and family members on smoking habits in adolescents were processed using the RevMan 5.3 application with the generic inverse-variance method. The results of the systematic study and meta-analysis were in the form of a forest plot and a funnel plot. The forest plot showed visually the variation in heterogeneity (Akobeng, 2005 in Murti, 2018). The funnel plot showed the relationship between the effect size of the study and the sample size of the various studies examined which could be measured in many different ways (Murti, 2018).

\section{The effect of peers on smoking habits in adolescents}

There were 12 articles of observational study with a cross-sectional design as a source of a meta-analysis of the effects of peers on smoking habits in adolescents. The result of the forest plot of the articles showed that peers who smoked 2.77 times increased smoking habits in adolescents; it was statistically significant $(\mathrm{aOR}=2.77$; $95 \% \mathrm{CI}=1.67$ to $\left.4.60 ; \mathrm{p}<0.001 ; \mathrm{I}^{2}=96 \%\right)$.

This is in line with a study conducted by tho et al. (2018), who conducted a survey in the spring of 2013 involving 34,776 secondary school students in Finland, that having close friends or peers of male and female who smoked increased smoking behavior in adolescents (37\% of women and $36 \%$ of men smoked every day).

Based on a study conducted by Smet et al. (2020) in Semarang, Indonesia, with a total sample of 6,276 middle-school students aged 11-17 years which aimed to determine the type of cigarette, the prevalence, and determinants of smoking behavior among adolescents showed that family members and peers who smoked increased significantly from $8.2 \%$ to $38.7 \%$.
Based on another study conducted by Balogun et al. (2020) in the Ibadan Utara area, Nigeria, with a total sample of 240 Public-Middle-School students aged 15-24 years showed that the involvement of parents who smoked and peer pressure who smoked increased smoking habits among adolescents ( $\mathrm{p}>0.001)$.

Nakaseko et al (2020) conducted a study among adolescents in the Republic of Vanuatu with a sample of 157 students in 7 th and 8th grade with a mean age of 13.3 years. It showed that parents, siblings, and peers who smoked increased significantly the smoking habit in adolescents in the Republic of Vanuatu ( $\mathrm{p}<0.05)$.

\section{The effect of family members on smoking habits in adolescents}

There were 8 articles of observational study with a cross-sectional design as a source of a meta-analysis of the effects of family members on smoking habits in adolescents. The result of the forest plot of the articles showed that family members who smoked 1.69 times increased smoking habits in adolescents; it was statistically significant $(\mathrm{aOR}=1.69 ; 95 \% \mathrm{CI}=1.35$ to $2.13 ; \mathrm{p}<0.001$; $\left.\mathrm{I}^{2}=65 \%\right)$.

This is in line with a study conducted by Balogun et al. (2019) that the involvement of parents who smoked and the parenting patterns of parents who smoked significantly affected attitudes towards smoking. Therefore, adolescents with smoking parents had the most positive tendency to smoke.

According to a study conducted by Skullberg et al. (2019) in Weh Island, Indonesia, having siblings and parents who smoked increased the risk factors for smoking in adolescents. More than a third of boys in the 13-15 year-age group were found to smoke. This is in line with a study conducted by Huang et al. (2012) that 
Apriliyani et al./ Effects of Peers and Family Members on Smoking Habits in Adolescents

family members increased the risk factors for smoking in adolescents.

Based on a study conducted by Gaffar et al. (2013), parents who smoked had a very high effect on the risk factors for smoking in adolescents. Another study conducted by Li et al. (2020) showed that the prevalence of males who smoked was significantly higher than females. This is supported by at least one of the parents who smoked.

According to Smet et al. (2020), children aged 11-15 years old were more susceptible to smoke. At 17 years of age, smoking behavior in adolescents has not only increased significantly but it would continue in their lifestyle, thus making them more difficult to quit smoking. However, the effects of the family who smoked with the risk of smoking uptake and its consequences for future health were aspects that have not been systematically reviewed and measured (Bee, 2011).

Based on a meta-analysis of 12 crosssectional studies of the effects of peers on smoking habits in adolescents, peers who smoked 2.77 times increased smoking habits in adolescents; it was statistically significant $(\mathrm{aOR}=2.77 ; 95 \% \mathrm{CI}=1.67$ to 4.60 ; $\left.\mathrm{p}<0.001 ; \mathrm{I}^{2}=96 \%\right)$.

Based on a meta-analysis of 8 articles of the effect of family members on smoking habits in adolescents, family members who smoked 1.69 times increased smoking habits in adolescents; it was statistically significant $(\mathrm{aOR}=1.69 ; 95 \% \mathrm{CI}=1.35$ to 2.13 ; $\mathrm{p}<0.001 ; \mathrm{I}^{2}=65 \%$ ).

This study was conducted by combining previous studies obtained from 17 primary studies conducted in several countries including Nepal, Italy, Saudi Arabia, Malaysia, Taiwan, Canada, Europe, Indonesia, Ethiopia, Bangladesh, and Finland.

\section{AUTHOR CONTRIBUTION}

Florida was the main researcher who selected the topic, searched, and collected the data. Agus Kristiyanto and Bhisma Murti played a role in analyzing the data and reviewing the documents.

\section{CONFLICT OF INTEREST}

This study did not have any conflict of interest.

\section{FUNDING AND SPONSORSHIP}

This study used personal funds from the main researcher.

\section{ACKNOWLEDGEMIENT}

We would like to thank the database provider such as PubMed, SpringerLink, Elsevier, Science Direct dan Google Scholar.

\section{REFERENCE}

Aho H (2018). The relationship between peer relations, self rated health and smoking behaviour in secondary vocational schools. Nurs Open. 6(3): 754764. https://dx.doi.org/10.1002\%2Fnop2.260.

Akl EA (2010). The effect of waterpipe tobacco smoking on health outcomes: A systematic review. Int J Epidemiol, 39(3): 834-857. https://doi.org/10.1093/ije/dyqoo2.

Alves J, Parelman J, Rojas VS, Richter M, Rimpela A, Loureiro I, Federico B, et al. (2016). The role of parenting smoking on adolescents smoking and its social patternin: A cross-sectional survey in six European Cities. J Public Health Dent, (39)2: 339-346. https://doi.org/10.1093/pubmed/fdw040.

Aminuddin MI (2018). Analisis faktorfaktor perilaku merokok di Sekolah Menengah Pertama Sunan Ampel: Skripsi. 
Apriliyani et al./ Effects of Peers and Family Members on Smoking Habits in Adolescents

Aryal UR (2014). Predictors of smoking suscepbility among adoescents findings from a Peri-urbaan Nepalese Community. Department of Internal Medicine and Nutrition Sahlgrenska, ISBN 978-91-628-8985-2 169-176.

Ayalu AR, Asmamaw MBY (2019). Determinants of cigarette smoking among adolescents in Ethiopia: A crosssectional study. Top Induc Dis, (17)9: 2-7. doi: 10.18332/tid/1108oo.

Backhaus I, D’Edigio V, Grassucci D, Gelardini M, Ardizone C, Torre GL (2017). Link between perceived smoking behaviour at school and students smoking status: a large survey among Italian adolescents. J Public Health, 151(2017): 169-176. http://dx.doi.org/10.1016/j.puhe.2017.07.004.

Bakhruji EA, Tantawi MME, Gaffar BO, AlKhalifa KS, Al-Ansari AA (2017). Carious lesions of permanent molars and oral health practices of parents and peers in Saudi male adolescents. Saudi Med J, (38)7: 748-754. doi: 10.15537/smj.2017.7.17601.

Ball J, Sim D, Edwards R (2018). Why has adolescents smoking declined dramatically? Trend analysis using repeat cross-sectional data from New Zeland 2005-2015. BMJ Open. 8(10): 1-8. doi: 10.1136/bmjopen-2017-020320.

Balogun SK, Famakinde PO (2019). Parental involvement, parentyng style and peer pressure as determinant of adolescents attitude towards cigarette smoking. Nigerian J Soc Psychol 2(1). https://nigerianjsp.com/index.php/N JSP/article/view/25/24.

Bee JA, Jere ML, Britton J (2011). Exposure to parental and sibling smoking and the risk o smoking uptake in childhood and adolescence: A systematic review and meta analysis. Thorax, 66:
847-855. doi:10.1136/thx.2010.153379.

Frieden TR, Centers of Disease Control Health and Inequalities Report (2013). Morbidity and mortality weekly report. Surveillance summaries, 62 (3): 1-2. Centers for Disease Control \& Prevention (CDC).

Gaffar AM, Alsanosy RM, Mahfous MS (2013). Sociodemographic factors associated with tobacco smoking intermediate and secondary school students in Jazan region of SAUDI Arabia. Subst Abus. 34(4): 381-8. https://doi.org/10.1080/08897077.2 013.779361.

Hashmi R, Pulok MH, Tannous K, Alam K (2014). Family and peers effect on young and adolescent smoking in Bangladesh. Research Square, http://orcid.org/oooo-0002-1733-5216.

Hiemstra M, Otten R, Engels RCME (2012). Smoking onset and the time-varying effects of self-efficacy, environmental smoking, and smoking-specific parenting by using discrete-time survival analysis. J Behav Med, 35(2): 240-251. doi: 10.1007/s10865-0119355-3.

Hiscock R, Bauld L, Amos A, Fidler JA (2012). Socioeconomic status and smoking: a review. Ann N Y Acad Sci. 1248(1): 107-123. doi: 10.1111/j.17496632.2011.06202.x.

Huang HL, Hsu CC, Peng WD, Yen YY, Chen T, Hu CY, Shi HY, et al. (20112). Analysis of influential factors associated with the smoking behavior of Aboroginal Schoolchildren in remote Taiwanese mountainous area. Journal of school health, 82(7): 318-327. https://doi.org/10.1111/j.1746-1561.2012.00705.x.

Humskey JL (2010). Are adolescents with high socioeconomic status more likely 
Apriliyani et al./ Effects of Peers and Family Members on Smoking Habits in Adolescents

to engage and illicit drug use in early adulthood?. BioMed Central, 5(19). doi:10.1186/1747-597X-5-19.

Illahi F (2015). Hubungan antara selfesteem dengan strategi coping 2.

Kementerian Kesehatan RI (2015). Perilaku merokok masyarakat Indonesia berdasarkan Riskesdas 2007 dan 2013. Pusat data dan informasi Kementerian Kesehatan RI. 2-12. doi: 24147659.

Kementerian Kesehatan RI (2011). Profil Kesehatan Indonesia 2010. Retrieved from http://www.depkes.go.id

Leatherdale ST, Cameron R, Brow KS, Jolin MA, Kroeker C (2010). The influence of friends, family, and older peers on smoking among elementary school students: Low-risk students in highrisk schools. Prev Med. 42(3): 218-22. https://doi.org/10.1016/j.ypmed.200 5.11.019.

Lee KJ (2014). Current smoking and secondhand smoke exposure and depression aamong Korean adolescents: Analysis of a national crosssectional survey. BMJ Open, 4(2): 1-7. doi: 10.1136/bmjopen-2013-003734.

Lehtren AE, Joronen K, Simila T, Rantanen A, Virtanen JI (2020). School achievement and oral health behaviour among adolescent in Finland: A National survey. Oral health Prev Dent, 18(2): 125-132. doi: 10.3290/j.ohpd.a43349.

Li LH, Pei HP, Huey TC, Cheong KC, Ghazali SM, Hock LK, Hui LJ (2020). Prevalence of smoking and its associated risk factors among secondary school students in Kelantan, Malaysia. Malaysian J Med Health Sci. 16(1): 44-50. https://medic.upm.edu.my/upload/dokumen/2020011611573107 _MJMHS_0417.pdf.
Lindstrom M, Sundquist J (2002). Ethnic differences in daily smoking in Malmo, Sweden. Eur J Public Health, 12(4): 287-294. https://doi.org/10.1093/eurpub/12.4.287.

Manafe MWN, Lerrick YF, Effendy BS (2019). Determinan tingkatan perilaku merokok remaja Kota Kupang. Jurnal Inovasi Kebijakan. 5(2): 51-59.

Moor I, Spallek J, Richter M (2015). Socioeconomic inequalities in adolescent smoking across 35 countries: A multilevel analysis of the role of family, school and peers. Eur J Public Health, 25(3): 457-463. doi: 10.1093/eurpub/cku244.

Nakaseko E, Kotera S, Nakazawa M (2020). Factors associated with smoking and dringking among early adolescents in Vanuatu: Across-sectional study of adolescents and their parents. Int $\mathrm{J}$ Environ Res Public Health. 17: 8412. doi: 10.3390/ijerph17228412.

Park MJ, Scoot JT, Adams SH (2014). Adolescent and young adult in the united states in the past decade: Little improvement and young adults remain worse off than adolescents. $J$ Adoesc Health, 55(1): 3-16. doi: 10.1016/j.jadohealth.2014.04.003.

Purba GB (2019). Studi identifikasi faktorfaktor yang mempengarui perilaku merokok pada siswa kelas XI di SMA Parulian Medan. Fakultas Psikologi: Universitas Medan Area.

Purnaningrum WD, Joebagio H, Murti B (2017). Association between cigarette advertisement, peer group, parental education, family income, and pocket money with smoking behavior among adolescents in Karanganyar District, Central Java. J Health Promot Behav. 2(2): 150-160. http://doi.org/10.26911/thejhpb.2016.02.02.05. 
Apriliyani et al./ Effects of Peers and Family Members on Smoking Habits in Adolescents

Putra HS, Rosemary R, Yanuar D, Ahsan A (2020). The effect of cigarette advertising on smoking behaviours of students in Banda Aceh city, Indonesia. Malaysian Journal of Communication, 36(2): 348-363. https://doi.org/10.17576/JKMJC-2020-3602-21.

Ratna AP, Munawir YSL (2019). Hubungan antara konsep diri dan konformitas dengan perilaku merokok pada remaja. Jurnal Psikologi, 15(2): 2026.

Reda AA, Moges A, Yazew B, Biadgilign (2012). Determinant of cigarette smoking among shool adolescents in Eastern Ethiopia: A cross-sectional study. Harm reduct J, 9(39): 1-6. doi: 10.1186/1477-7517-9-39.

Reidpath DD, Davey TM, Kadirvelu A, Soyiri IN, Allotey P (2014). Does one cigarette make an adolescents smoker, and is it influenced by age and age of smoking initiation? Evidence of association from the U.S youth risk behavior surveillance system. Preventive Medicine, 59(1): 3741. doi: 10.1016/j.ypmed.2013.11.011.

Riadinata (2018). Hubungan keluarga dan teman sebaya dengan perilaku merokok pada remaja usia 18-22 tahun di Desa Gonilan Kartasura. Artikel publikasi, Universitas Muhammadiyah Surakarta.

Rostron BL, Chang CM, Pechacek TF (2014). Estimation of cigarette smoking attributable morbidity in the United States. JAMA intern Med. 20993(12): 1922-1928. doi: 10.1001/jamainternmed.2014.5219.

Santrock JW (2007). Remaja jilid 2. Jakarta: Erlangga.

Saravan C, Attlee A, Sulaiman N (2019). A cross-sectional study on knowledge, beliefs and psycosocial predictors of sisha smoking among univerity stu- dents in Sharjah, United Arab Emirates. Asian Pac J Cancer Prev, 20(3): 903-909. doi: 10.31557/APJCP.2019.20.3.903.

Septiana N, Syahrul, Hermansyah (2016). Faktor keluarga yang mempengaruhi perilaku merokok pada siswa sekolah menengah pertama. Jurnal Ilmu Kesehatan, 4(1).

Simbeee G (2012). Prevalence of substance use and psycosocial influencing factors among secondary school students in Dodoma municipality gema Simbee. Dissertation Muhimbili University of Health Aalied Science, 1-12.

Simetin IV, Kuzman M, Franelic IP, Pristas I, Benjak T, Dezeljin JD (2011). Inequalities in Croatian pupils unhealthy behaviours and health outcomes: Role of school, peers and family affluence. Eur J Public Health, 21(1): 122-128. doi: 10.1093/eurpub/skq002.

Skullberg KR, Hamid S, Vaktskjold A (2019). Smoking among adolescent males at Pulau Weh, Indonesia. Public Health J, 5(3): 62-70.

Smet B (2020). Determinant of smoking behaviour among adolescents in Semarang, Indonesia. BMJ Open, doi: 10.1136/tc.8.2.186.

Tapera R (2020). The Theory of planned behavior change for tobacco control strategies among adolescents in Bostwana. PLos ONE 15(6): eo233462. https://doi.org/10.1371/journal.pone.0233462.

USDHHS (2014). Can we use them to make combusting of tobacco absolete-end the cigarette century and its preventable deathts? U.S Departement of health and human services. The health consequences of smoking 50 years of progress: A report of the surgeon general. U.S Departement of 
Apriliyani et al./ Effects of Peers and Family Members on Smoking Habits in Adolescents

health and human services centers for disease control and prevention, national center, 51 .

Villanti A, Boulay M, Joun H (2011). Peer, parent and media influence on adolescents smoking by developmental stage. Addictive behavoiors. 36(1-2): 133-6. https://doi.org/10.1016/j.addbeh.2010.08.018.

Waziry R, Jawad M, Ballout RA, Akel MA, Akl EA (2017). The effects of water- pipe tobacco smoking on health outcomes: An updated systemtic review and meta-analysis. Int J Epidemiol, 46(1): 32-43. https://doi.org/10.1093/ije/dywo21.

World HealtH Organization (2011). Top 10 cause of death Switzerland.

World Health Organization (2017). Monitoring Tobacco use and prevention policies. 